Оригинални научни рад

УДК 811.163.41'373.21(497.6)

Примљен: 1. новембар 2020.

Прихваћен: 28. март 2021.

Жарко Б. Вељковић ${ }^{1}$

https://doi.org/10.46630/phm.13.2021.40

Српски научни центар, Београд

Милан Ж. Војновић

Универзитет у Београду

Филозофски факултет

Студент докторских студија

\title{
НУДМИР И ЛУДМЕР: ЈОШ ЈЕДНОМ О ТОПОНИМУ
}

\begin{abstract}
У чланку се полази од расветљујућег и обухватног рада о етимологији источнобосанског топонима/хоронима Лӱдмер и Лудмѐрија Александра Ломе, где је аутор са опрезом дао „хипотетичну реконструкцију” као закључак, услед немогућности да пронађе недвосмислене историјске потврде пре 1900. Даљом претрагом, проналазе се додатне историјске потврде, или пак нова читања старих у периоду 1530-1712/13, као и прва недвосмислена историјска потврда 1363. у облику ${ }^{\star} Н \ddot{y} д м \bar{p} р$ и Нудмѝрија, на лат. Nudmiria. Коригује се Ломина етимологија тако да топоним/хороним потиче од ${ }^{\star} Н \ddot{y} \partial м \bar{u} p$ (ген.

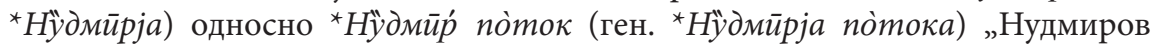
поток”, што је изведено од личног имена Нйдмйр, старије, несинкопирано, ${ }^{*} Н \ddot{y} д и м \bar{и}$. Ово старо српско лично име Ноүдьмнрь забележено је у Крушевском поменику из времена пре краја XV в., а значење му је „ко (силом) принуди на / изнуди (мировни) споразум, мир", и спада у тип имена̂ на -мйр са негативном семантиком.
\end{abstract}

Кључне речи: Лудмер, Лудмерија, Нудмир, Нудмирија, Nudmiria, *Нудимир, топоним, етимологија.

Лўдмер (ген. Лўдмера) народни је назив за предео у источној Босни који је са суседним пределом Осат некада чинио Сребренички срез/ котар, а заимају га и мёђе̄ поток Крижевац и три реке, Дрина, Дрињача и Јадар (JEREMIĆ 1922: 143; LOMA 1998: 13, 15). Његови становници називају се Лудмерани, и за себе ће с поносом, заправо шаљиво казати да су „љута Лудмерија” (GRĐIĆ-BJELOKOSIĆ 1900: 587; LOMA 1998: 15). У односу на околину, Лудмерани имају своје засебне обичаје и изражену свест о себи, посебно у односу на првосуседне Осаћане и Осат (уп. GRĐIĆ-BJELOKOSIĆ 1900: 588; LOMA 1998: 15).

О пореклу имена Лудмер своја мишљења дало је досада низ научних радника. Грђић-Бјелокосић износи тврдњу да су Лудмер и 1 sapphousatthis@gmail.com 
Лудмерани „[о]во име [...] по свој прилици добили по једном доста незнатном и малом врелу и потоку у Кравици, које [врело] се зове истијем именом 'Лудмер"' (GRĐIĆ-BJELOKOSIĆ 1900: 587; LOMA 1998: 15). Скарић пак претпоставља „да нека имена [у Босни] могу да подсећају на колонизацију из доба угарског владања у XIII веку или пре”, и ту прибраја Литва и Лудмер, које пореди са негдашњим називом Лодомерија за део закарпатске Галиције, а његово мишљење преносећи усваја и Јеремић (1922: 146; LOMA 1998: 15). Сергејевски износи опаску да њему име Лудмер звучи „роsve tuđinski”, док је Вегу оно „slovenskog porijekla i po svome izgovoru i po svršetku riječi” (SERGEJEVSKI 1952: 5; VEGO 1957: 69; LOMA 1998: 15). Лома на тему даје расветљујући и обухватан рад, али ипак - услед немогућности да пронађе недвосмислене историјске потврде пре 1900. г. - бивајући „принуђе[н] да прибегн[е] хипотетичним реконструкцијама”, каже као закључак следеће: „, [...] можемо рећи да је, упркос свим изнесеним недоумицама, хороним Лудмер по пореклу највероватније хидроним, и то посесивно образовање на -jb у мушком роду према поток од прасловенског личног имена ${ }^{\star} L^{\prime} u d b-m e ̌ r z /{ }^{\star} L^{\prime} u d i$ $m[\bar{i}] r z$ или сл., са пуном аналогијом у пољском топониму Ludzimierz." Додаје и то да би се „на основу овог историјско-етимолошког увида морало [...] допустити да се у топонимима на -мер, -мерићи у источној Босни и суседним деловима Србије реликтно чува антропонимски елеменат -mе̌r некада шире присутан на српском и хрватском терену, ${ }^{2}$ a доцније готово сасвим потиснут од $-m[\bar{i}] r$. Ја то ипак не смем тврдити. Без обзира на вокализам свога другог члана, сва ова имена су у једном доста раном периоду могла и овде бити уједначена у корист варијанте са -i-, да би доцније претрпела дијалекатску промену $-[\bar{u}] p>-[\overline{\mathrm{k}}] p$. Другим

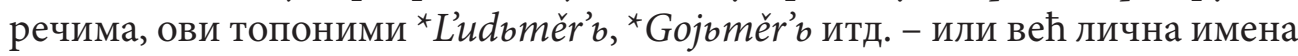
која су им у основи - ако и јесу тако изворно гласили, могли су најпре под утицајем типа на $-\mathcal{M}[\bar{u}] p$ дати ${ }^{\star} \precsim y \partial м[\bar{u}] p$, Гојм $[\bar{u}] p$ итд., и тек знатно касније попримити своју данашњу форму Лудмер, Гојмер итд. Нагласимо још и да хипотеза о исконском јату у овим именима, као и она о његовом секундарном настанку, имплицира проблем његових екавских рефлекаса, тј. некадашње шире распрострањености прелаза $\overline{\mathrm{E}}>е$ у источној Босни и Подрињу" (LOMA 1998: 14, 15, 24, 25).

2 Према примеру из Туропоља 1427. и 1459. који Лома такође прилаже (LOMA 1998: 24), морало би се пак додати и и словеначком, будући да је кајкавски до XVIII в. (када је ушао у сферу хрватства и хрватског језика), био именован slovensko slovo, slovenščina и slovensk $i$ jezik, а његово говорно подручје Slovenski orsag, нпр. 1651. по речима рођенога жумберачког кајкавца и загребачког бискупа Петра Петретића (KUKULJEVIĆ-SAKCINSKI 1868: 312-318; VELJKOVIĆ 2018: 296, в. и 297; IVIĆ 1971: 34-37). Истим прецизн(иј)им методолошким приступом, у савременој историјској литератури хришћански великодостојници на данашњем католичком Западу у времену до Велике схизме (1054) зову се општехришћанским термином епископи и архиепископи, а не бискупи и надбискупи. 
Као што смо изнели, Лома није био у могућности да пронађе недвосмислене историјске потврде топонима Лудмер пре 1900. Наиме, Лома каже: „По Марку Вегу [...] (1957: 69), Лудмер се помиње први пут 1363, но облик у којем је име дато у извору он не цитира, а у зборнику дубровачких докумената на који се за тај податак позива (TADIĆ 1935) ово име не налазимо, ни на страни 146 на коју Вего упућује - а где су писма из 1366. [г.] - нити у писмима из наведене 1363. године [...] (105-122), па ни у исцрпном регистру имена на крају књиге. Овај негативан налаз утолико више разочарава, што су и доцнији историјски записи нашег топонима практично неупотребљиви, Наиме, у турским пописима из $1476 / 77,1519,1533$. и 1548. уз нахије смештене у истом делу Подриња (Сребреница, Шубин, Кушлат) бележи се нахија чије име и Ханџић и Шабановић у свим случајевима сложно читају 'Будимир', 'Будмир', узимајући да се ради о данашњем пределу Лудмеру, у који се заиста броје идентификована села те нахије (HANDŽIĆ 1975: 51, 1986 : 25, 81; ŠABANOVIĆ 1982: 171). Да је у једном наврату при бележењу овог имена дошло до писарске замене почетног слова према обичнијем имену Будимир, са́мо по себи је вероватно; кӓко се, међутим, погрешан облик могао усталити и деценијама трајати у административној употреби, није јасно. [...] Ако је облик Будимир стварно постојао на овом терену, не видим никакву могућност да се познатим језичким развојима од њега дође до Лудмер. ${ }^{2}\{2:$ Могло би се помишљати на упрошћење од (иначе

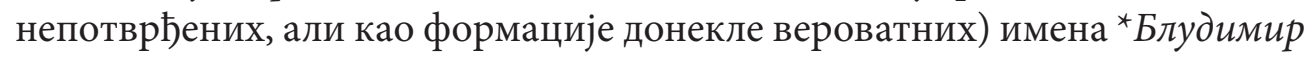

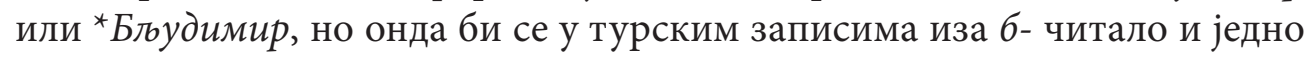
л.\} [...] \{25: [...] Колико се да проверити са слабо читљивих факсимила у прилогу књиге [А.] Ханџић[а] (1986), име нахије 'Будимир' је 1519. записано $b w d m y r(\mathrm{I}, 2)$, a 1533. (II, 2) на исти начин, само без дијакритика̂, дакле отприлике øwdmr по транскрипцији коју је предложио Пешикан (1981).\}” (LOMA 1998: 14, 21). Ипак, Лома истиче како „[о]стаје нада да ће будућа истраживања ипак изнети на светло дана неку ранију [недвосмислену] потврду [пре 1900] нашег имена, и неће бити никаква штета ако она покоју од овде изнетих претпоставки учини излишном, или је разобличи као погрешну" (LOMA 1998: 15).

Са таквим добрим жељама овог великог аутора, даљом претрагом наишли смо на следеће додатне историјске потврде хоронима Лудмер, или пак на нова читања старих:

У турском попису из 1533. убележена је нахија „Подмир” (Podmir n.) у кази Сребреница (Srebreniçe kz.) у ливи Зворник (İzvornik 1.) (UNAL, BUDAK i dr. 2013: 23, 24, 679; SARINAJ, BUDAK i dr. 2005: 3, 227). Овај облик имена нахије „Подмир” - према знаку ø за срп. $6, n, m, \mu, j, u$ (плус „®”, \{??) шипт. th) у транскрипцији коју је дао Пешикан (1981: 92, 96-98, 
$100,106,1982: 6,7)$ - јасно указује на облик отпр. øwdm(y)r, а који Лома са успехом чита као отпр. øwdmr са (заиста слабо читљивих факсимила) у прилогу књиге А. Ханџића (1986).

У турским пописима из 1530, можда 1533-74, 1548/49, 157495, 1606/07. те 1705/06-1712/13. убележена је нахија „Подмир” (nāhiye: Podmir) у кази Брвеник (kazā: Birvenik) у ливи Зворник (livā: İzvornik), нахија „Подмир” (nāhiye: Podmir), нахија „Подмир” (nāhiye: Podmir) у кази Шабац (kazā: Böğ̈̈r-delen) у ливи Зворник (livā: İzvornik), нахија „Подмир” (nāhiye: Podmir), нахија „Подмир” (nāhiye: Podmir) у кази Шабац (kazā: Bögü̈r-delen) те нахија „Подмир” (nāhiye: Podmir) у ливи Зворник (livā: İvornik) (SARINAJ, BUDAK i dr. 2005: 21, 22, 23). И овај облик имена нахије „Подмир” - према транскрипцији коју је дао Пешикан $(1981,1982)$ - јасно указује на облик отпр. $ø w d m(y) r$.

Треба додати и то да обадва регистра турских пописа из којих поменуте потврде преузимамо јасно разликују облик „Подмир” (Podmir) од облика Буд(u)мир и сл. (Budmir, Budimirçi) (UNAL, BUDAK i dr. 2013: 155; SARINAJ, BUDAK i dr. 2005: 119), што онда јасно указује на писање са знаком ø-, односно отпр. øwdm(y)r. То би значило да се у периоду 1530 $1712 / 13$. у турским пописима генерално находи облик отпр. øwdm $(y) r$, а облик са дијакритицима $b w d m y r$ из 1519. који проверава и доноси Лома био би писарска грешка, управо како он и каже, резултат „писарске замене почетног слова према обичнијем имену Будимир" (LOMA 1998: 14), док би, с друге стране, сва потоња читања правилно записаног облика отпр. $ø w d m(y) r$ као „Будмир” или „Будимир” била плод повођења, у најбољој методичкој намери, за овом хронолошки старијом писарском грешком.

Облик отпр. øwdm(y)r се према транскрипцији коју је дао Пешикан $(1981,1982)$ може читати са завршним -up, -ер, -ијер или -јер, а почетни слог може се читати не само са По-/Пу-, него и са Бо-/Бу-, То-/ Ty-, Ho-/Hy-, Jo-/Jy-. На тај начин, остајући у оквирима етимологије коју је предложио Лома (1998), од `људимйр, овде би се могло помислити и на секундаран облик ${ }^{\star} J y \partial м \bar{u} p /^{*} J y \partial м \overline{\mathrm{⿷}} p /^{\star} J y \partial м е р$ са дијалекатском гласовном променом $\pi_{b}>j$ која се у локалном ијекавскошћакавском говору спорадично јавља, да цитирамо, „[s]onanti $l j$ i $n j$ imaju dosta nestabilnu artikulaciju, a lj može da prelazi u j" (РECO 1980: 97). Тај би претпостављени облик ${ }^{*} J y \partial м \bar{u} p /^{*} J y \partial м \overline{\mathrm{⿷}} p{ }^{*} J y \partial м е р$ потом био преобличен на почетно Лпрема другде постојећем топониму Лудмйр/^Лудмฐ̄ $/$ Лудмер, који је посведочен 1475/77. као Лудмир, мезра (селиште) у селу Гребешник код

3 Стављамо -(y)- јер Пешикан у предлогу транскрипције каже: „Нарочито се радо изостављају самогласници $е$ и $u$ [...]" (PEŠIKAN 1982: 6).

4 Потврде су нанизане одговарајућим хронолошким редом. 
Кукања, западно од Пљеваља, али и као хипотетични ${ }^{5}$ старији облик имена висова Горюи и Доюи Лумер југозападно од Биоградског језера код Мојковца. ${ }^{6}$ Такође, био би можда преобличен на почетно Л(yd)(и) реетимологијом према придеву луд у дескриптивним топонимским синтагмама попут Лудо поље (ALIČIĆ 1985: 51; LOMA 1998: 14, 18).

Међутим, 10. октобра 1363, приликом дубровачке исплате дохотка могориша за 1363. г. остало је забележено да је то учињено (лат.) presentibus [...] Radossiō Popovich aurificĕ de Cuçlath et Radossiō Milchovich de Nudmiriā, hominibus Purche voyvode de Bosnā „у присуству сведока Радоша Поповића, златара из 〈! Кучлата, и Радоша Милковића из 〈! Нудмѝрије̄, који су људи од поверења војводе Пурће (Дабишића) из Босне” (DINIĆ 1955: 49).

Мала напомена. У првом делу књиге Михаила Динића о рударству у средњовековној Босни и Србији, која ово место и доноси, на ово место стављена је фуснота 15 да означи извор одакле је преузето: „Distrib. Test. 2 fol. 14', 10. X 1363.” Док, наредна фуснота (16), такође да означи извор, за извесно друго место, гласи: „Тадић, o[pus] с[itatum], 146” (DINIĆ 1955:

5 Лома саิм употребљава ову реч „у недостатку историјских потврда”, а опреза ради. Помишља чак и на могућност да је ороним Лумер од италијанизма лумер „број” (< итал. numero), али му та реч не одговара ни ареално ни у орографској примени (LOMA 1998: 14). Ми бисмо хипотетички помислили за овај ороним да је романизам или од романизма пореклом (са суфиксом или без њега) од латинске речи lumen „светлост, даิње светло / дан, светиљка, око (сјајно)", те би тако Горни и Доюи Лумер хипотетички били „два планинска гола, каменита врха с којих се сјакти светлост сунца / даิње светло, два планинска светла врха на истоку преко којих (као да) свањава дан, (?) два планинска врха - планинска ока сјајна” и сл.

6 Поред тога, у Рачанском поменику из XVII и делимично XVIII в. јавља се име села Нудмер (н8А'мерь) (JOVANOVIĆ 2005: 177а) које се на другом месту у поменику - врло извесно - јавља забележено као Нунмер (н8н'мерь) (158a; LOMA 2005: 461, 468), а данас је то село у ваљевској Колубари Наномир између двају ваљевских села, Дегурић и Љубинић (LOMA 2005: 468). Лома је мишљења да „није јасно да ли иза овога записа стоји исти гласовни лик, где је н прочитано уместо А, или је посреди његова реална фонетска варијанта са развојем $\partial \mathcal{M}>\mathcal{H M}^{\prime}$, где бисмо „могли [...] имати прелазни облик ка данашњем имену села Наномир [...] уз претпоставку да је дошло до накнадног преосмишљења првог дела овог топонима" (LOMA 2005: 468). Ипак, наше је скромно мишљење да је

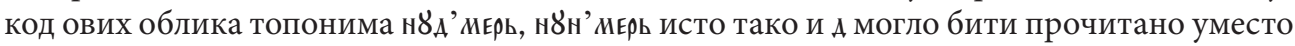
н, те да бисмо најпре очекивали фонетски развој $\partial \mathcal{M}>\mathcal{M}, \mathcal{M M}$ (ödmāh > ömā $(\mathrm{h} h)$, ömmā $(\mathrm{h} \hat{)})$ који се јавља, нпр., у (суседној) источној Босни (РЕСО 1980: 97), а хипотетички би се јавио и код поменутога оронима (Горни и Доғи) Лумер југозападно од Биоградског језера код Мојковца (в. горе). Стога, а и будући да за овај топоним н४А'мерь, н४н'мерь, Наномир „[н]е располажемо његовим старијим записима” (LOMA 2005: 468; такође, нема у UNAL, BUDAK i dr. 2013), ми га за тему коју у чланку разматрамо ипак сматрамо засада непоузданим, и вероватно не(по)везаним. Најхипотетичкије, могло би се код овога топонима и имена н8н'мєрь помишљати на упрошћење од (иначе непотврђеног, али као формације донекле вероватног) имена ${ }^{\star}$ Нујномир „ко је нујан, тужан, безвољан и у муци када / ко с тугом, невољно и с муком склапа (мировни) споразум, мир”. 
49). Преносећи из овога места податак о првом помену Лудмера 1363, Вего је у својој књизи о насељима средњовековне Босне (VEGO 1957: 69) погрешно цитирао извор - из погрешне фусноте, и отуда Лома (1998) није био у могућности да пронађе текстуално место првога помена и прву недвосмислену историјску потврду Лудмера 1363, те да да̂ етимологију овог топонима без „недоумица” и „хипотетичних реконструкција”.

На овај описани начин, долазимо до облика топонима/хоронима Лӱдмер и Лудмѐрија у XIV в. ${ }^{*} H \ddot{\partial} д м \bar{р} р$ и Нудмиेрија. У складу са Ломиним етимолошким решењем (LOMA 1998), изворно ${ }^{*} H \ddot{y} \partial м \bar{u} p$ (ген. $\left.{ }^{\star} H \ddot{y} \partial м \bar{u} p j a\right)$ односно ${ }^{\star} Н \bar{y} д м \bar{u} p ́$ по̀ток (ген. ${ }^{\star} Н \bar{y} \partial м \overline{и р j а ~ п о ̀ т о к а) ~ „ Н у д м и р о в ~ п о т о к ”, ~}$ изведено од личног имена Нӱдмйр, старије, несинкопирано, ${ }^{\star} H \ddot{y} \partial и м \bar{u} р$.

Речник тичних имена код Срба доноси нам старо српско лично име Нудмир, преузимајући га из збирке-речника српских имена из поменика̂, Српски поменищз XV-XVIII века (GRKOVIĆ 1977: 14, 148), где и проналазимо лично име Нудмир (речн. Ноүдьмнрь) из Крушевског поменика из времена пре краја XV в., које је прибележено - логично - у акуз. Нвдмира (NOVAKOVIĆ 1875: 17-19, 86).

Почетно Л- у облику Лудмер постало је од почетнога $H$ - ${ }^{*}$ Нудмир дијалекатским разједначавањем сугласника̂ $H: \mathcal{M}>\pi: \mathcal{M}$ као у речима нумер > лумер, снимати, снимам > слимати, слимам, снимити, снимим > слимити, слимим, знамене > зламене, поднимача > подлимача (SKOK 1 1971: 778, 2 1972: 528; BELIĆ 1976: 143). Оно се пак у топонимији не сматра дијалекатским, тј. узима се так(в)о какво јесте, за шта упоредити

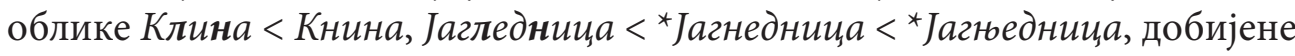
врло сличним разједначавањем сугласника̂ $\mathcal{H}: \mathcal{H}>\pi: \mathcal{H}$ (в. LOMA 2013: 272).

Напослетку, о самом личном имену Нйдмӣp, старије, несинкопирано, ${ }^{\star} Н \ddot{y} \partial и м \bar{u}$. Оно је императивна сложеница од глагола нудити у значењу „принудити на / изнудити” (уп. MARETIĆ 1887: 125; LOMA 2005: 468) и општесловенске антропонимске основе -мйр у значењу „(мировни) споразум, мир”, несловенског, староиранског скитског порекла, од * mi(h)r- „споразум, уговор” (в. LOMA 1998: 18, 21 , 22). Име ${ }^{\star} Н \ddot{y} \partial u м \bar{р} р$ у значењу „ко (силом) принуди на / изнуди (мировни) споразум, мир" има делимичну аналогију у старочешком имену ${ }^{*} \mathrm{Nud}(\mathrm{i})$ voj „ко (силом) принуди на / изнуди војну, војевање, рат”, посведоченом кроз топоним Nudvojovice (SVOBODA 1964: 96; уп. PROFOUS, SVOBODA i dr. 3 1951: 237; LOMA 2005: 468). Спада у тип именâ на -мӣp са негативном семантиком попут имена̂ Мутимир „ко помути, поремети, наруши/ нарушава (мировни) споразум, мир”, Лажимир „ко лаже да жели / лажно склапа (мировни) споразум, мир”, “Кудимир „ко покуди па порекне/ пориче (мировни) споразум, мир”, Казимир „ко унакази, уништи/ 
уништава (мировни) споразум, мир” и сл. (LOMA 1998: 18, 19).

А ако би се коме можда учинила зачудна ова семантичка комбинација, „нудитu, принудити на / изнудити” и „мир”, можемо понудити семантичку комбинацију (под знаком питања), „утихнути” и „мир”, у имену *Утихнимир (a)u, или сл., односно *Утихнимир или *Утихнимь $р$ (посведоченоме можда кроз презиме Утихьрчић у Ливну 1400) (VELJKOVIĆ 2018: 288-290; NAKAŠ 2011: 3803), исто тако и семантичку комбинацију коју Лома помиње, „полу-” и „мир”, у имену Полумир у Ибру (LOMA 1998: 19).

\section{Цитирана литература}

ALIČIĆ, Ahmed S. (prir.). Poimenični popis sandžaka vilajeta Hercegovina (Orijentalni institut u Sarajevu. Monumenta Turcica historiam Slavorum «!! meridinalium 〈!! ilustrantia. Tomus sextus. Serija II. Defteri. Knjiga 3). izd. Sarajevo: Orijentalni institut u Sarajevu, 1985.

BELIĆ, Aleksandar. Osnovi istorije srpskohrvatskog jezika I. Fonetika. Univerzitetska predavanja A. Belića. Knj. 1. izd. Beograd: Naučna knjiga, 1976. [orig.] Белић, Александар. Основи историје српскохрватског језика I. Фонетика. Универзитетска предавања А. Белића. Књ. 1. изд. Београд: Научна књига, 1976.

DINIĆ, Mihailo J. Za istoriju rudarstva u srednjevekovnoj Srbiji i Bosni. I deo (Srpska akademija nauka i umetnosti. Posebna izdanja. Knjiga CCXL. Odeljenje društvenih nauka. Knjiga 14). Knj. 1. izd. Beograd: Srpska akademija nauka i umetnosti, 1955. [orig.] Динић, Михаило J. За историју рударства y средневековној Србији и Босни. I део (Српска академија наука и уметности. Посебна издања. Књига CCXL. Одељење друштвених наука. Књига 14). Књ. 1. изд. Београд: Српска академија наука и уметности, 1955.

GRĐIĆ-BJELOKOSIĆ, Luka. „Banalački (radnički, dunđerski) jezik”. Glasnik zemaljskog muzeja u Bosni i Hercegovini, god. XII, knj. XII (1900): str. 587591. [orig.] ГРЂИЋ-БЈЕЛОКОСИЋ, Лука. „Баналачки (раднички, дунђерски) језик”. Glasnik zemaljskog muzeja u Bosni i Hercegovini, год. XII, књ. XII (1900): стр. 587-591.

GRKOVIĆ, Milica. Rečnik ličnih imena kod Srba. izd. Beograd: Vuk Karadžić, 1977. [orig.] Грковић, Милица. Речник тичних имена код Срба. изд. Београд: Вук Караџић, 1977.

HANDŽIĆ, Adem. Tuzla i njena okolina u XVI vijeku. izd. Sarajevo: Svjetlost, 1975. HANDŽIĆ, Adem. Dva prva popisa Zvorničkog sandžaka (iz 1519. i 1533. godine) (Akademija nauka i umjetnosti Bosne i Hercegovine. Srpska akademija nauka i umetnosti. Građa. Knjiga XXVI. Odjeljenje društvenih nauka. Knjiga 22). izd. Sarajevo: Akademija nauka i umjetnosti Bosne i Hercegovine, Srpska akademija nauka i umetnosti, 1986.

IVIĆ, Pavle. Srpski narod i njegov jezik (Srpska književna zadruga. Kolo LXIV. Knjiga 
429). izd. Beograd: Srpska književna zadruga, 1971. [orig.] Ивић, Павле. Српски народ и юегов језик (Српска књижевна задруга. Коло LXIV. Књига 429). изд. Београд: Српска књижевна задруга, 1971.

JEREMIĆ, Risto. „O poreklu stanovništva tuzlanske oblasti - beleške -”. Glasnik Geografskog društva, knj. 7-8 (1922): str. 141-157. [orig.] ЈЕРЕМИЋ, Ристо. „О пореклу становништва тузланске области - белешке -”, Гласник Геограбског друштва, књ. 7-8 (1922): стр. 141-157.

JOVANOVIĆ, Tomislav. Pomenik manastira Rače. izd. Bajina Bašta: Fondacija Račanska baština. [orig.] Јовановић, Томислав. Поменик манастира Раче. изд. Бајина Башта: Фондација Рачанска баштина, 2005.

KUKULJEVIĆ-SAKCINSKI, Ivan (ur.). „Petar Petretić (III. Književna «! povjestnica. IV. «! Povjestnici)”. Arkiv za 〈! povjestnicu jugoslavensku, knj. IX (1868): str. 312-325.

LOMA, Aleksandar. „Ludmer”. Srpski jezik, god. III, knj. 3, sv. 1-2 (1998): str. 13-29. [orig.] ЛОМА, Александар. „Лудмер”, Српски језик, год. III, књ. 3, св. 1-2 (1998): стр. 13-29. (DOI) 808-311

LOMA, Aleksandar. „Na imenoslovnim vrelima II. Osvrt na nova izdanja starosrpskih izvora (Osvrti)”. Onomatološki prilozi, knj. XVIII (2005): str. 457-472. [orig.] ЛОМА, Александар, „На именословним врелима II. Осврт на нова издања старосрпских извора (Осврти)", Ономатолошки прилози књ. XVIII (2005): стр. 457-72.

LOMA, Aleksandar. Toponimija Banjske hrisovulje. Ka osmišljenju srpskog toponomastičkog rečnika i boljem poznavanju opšteslovenskih imenoslovnih obrazaca (Srpska akademija nauka i umetnosti. Odeljenje jezika i književnosti. Odbor za onomastiku. Biblioteka onomatoloških priloga. Knjiga 2). izd. Beograd: Srpska akademija nauka i umetnosti, 2013. [orig.] Лома, Александар. ТопонимијаБағскехрисовуле. Каосмишљенусрпскогтопономастичког речника и болем познавану општесловенских именословних образаца (Српска академија наука и уметности. Одељење језика и књижевности. Одбор за ономастику. Библиотека ономатолошких прилога. Књига 2). изд. Београд: Српска академија наука и уметности, 2013.

MARETIĆ, Tomislav. „O narodnim imenima i prezimenima u Hrvata i Srba”. Rad Jugoslavenske akademije znanosti i umjetnosti, knj. 82 (1887): str. 69-154.

NAKAŠ, Lejla (prir.). Konkordancijski rječnik ćirilskih povelja srednjovjekovne Bosne (Društvo za proučavanje srednjovjekovne bosanske historije. Posebna izdanja. Knjiga X. Rječnici. Svezak 1). izd. Sarajevo: Društvo za proučavanje srednjovjekovne bosanske historije, Filozofski fakultet u Sarajevu, 2011.

NOVAKOVIĆ, Stojan. „Srpski pomenici XV-XVIII veka”. Glasnik Srpskog učenog društva, knj. XLII (1875): str. 1-153. [orig.] НОВАКОВИЋ, Стојан. „Српски поменици XV-XVIII века". Гласник Српског ученог друштва, књ. XLII (1875): стр. 1-153.

PECO, Asim. Pregled srpskohrvatskih dijalekata. izd. Beograd: Naučna knjiga, 1980. PEŠIKAN, Mitar. „O upotrebljivosti onomastičkih podataka iz turskih teftera”. Južnoslovenski filolog, knj. XXXVII (1981): str. 91-108. [orig.] ПЕШИКАН, Митар. „О употребљивости ономастичких података из турских 
тефтера”. Јужнословенски филолог, књ. XXXVII (1981): стр. 91-108.

PEŠIKAN, Mitar. „Zetsko-humsko-raška imena na početku turskoga doba. I. Uvodna razmatranja”. Knj. 1. Onomatološki prilozi, knj. III (1982): str. 1-121. [orig.] ПЕШИКАН, Митар. „Зетско-хумско-рашка имена на почетку турскога доба. І. Уводна разматрања”. Књ. 1. Ономатолошки прилози, књ. III (1982): стр. 1-121.

PROFOUS, Antonín, SVOBODA, Jan, ŠMILAUER, Vladimír. Místní jména $v$ Čechách. Jejich vznik, pưvod, význam a změny I-V. Knj. 1-5. izd. Praha: Československá akademia věd, 1947-1960.

SARINAY, Yusuf, BUDAK, Mustafa, BAYIR Önder, IZGÖER, Zeki. 91, 164 MAD 540 ve 173 numarali Hersek, Bosna ve İzvornik livâlari icmâl tahrîr defterleri (926-939/1520-1533) (T. C. Başbakanlık. Devlet Arşivleri Genel Müdürlüğü. Osmanlı Arşivi Daire Başkanlığı. Yayın Nu: Defter-i-Hâkânî Dizisi: X). izd. Ankara: Devlet arşivleri genel müdürlüğü, 2005.

SERGEJEVSKI, Dimitrije. Ludmer (Zemaljski muzej u Sarajevu. Srednjevjekovni nadgrobni spomenici Bosne i Hercegovine. Svezak IV). izd. Sarajevo: Zemaljski muzej u Sarajevu, 1952.

SKOK, Petar. Etimologijski rječnik hrvatskoga ili srpskoga jezika. Uredili akademici Mirko Deanović i Ljudevit Jonke. Surađivao u predradnjama i priredio za tisak Valentin Putanec. Knjiga prva. A-J. Knjiga druga. K-poni ${ }^{1}$. Knjiga treća.

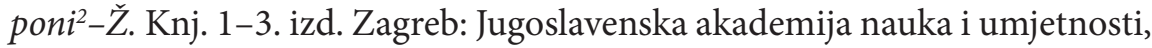
1971-1973.

SVOBODA, Jan. Staročeská osobní jména a naše př́imení. izd. Praha: Československa akademia věd, 1964.

ŠABANOVIĆ, Hazim. Bosanski pašaluk. Postanak i upravna podjela. izd. Sarajevo: Svjetlost, 1982.

TADIĆ, Jorjo (obj.). Pisma i uputstva Dubrovačke republike. Knjiga I (Srpska kraljevska akademija. Zbornik za istoriju, jezik i književnost srpskog naroda. Treće odeljenje. Knjiga IV. Fontes rerum Slavorum meridionalium. Editi cura Johannis Radonić. Series secunda). Knj. 1. izd. Beograd: Srpska kraljevska akademija, 1935. [orig.] Тадић, Јорјо (обј.). Писма и упутства Дубровачке републике. Кюига I (Српска краљевска академија. Зборник за историју, језик и књижевност српског народа. Треће одељење. Књига IV. Fontes rerum Slavorum meridionalium. Editi cura Johannis Radonić. Series secunda). Књ. 1. изд. Београд: Српска краљевска академија, 1935.

ÜNAL, Uğur, BUDAK, Mustafa, BAYRAM, Sabahattin, YILDIZTAŞ, Mümin. Rumeli eyaleti (1514-1550) (T. C. Başbakanlık. Devlet arşivleri genel müdürlügüu. Osmanlı arşivi daire başkanlığı. Yayın Nu: Osmanlı yer adları: I). izd. Ankara: Devlet arşivleri genel müdürlüğü, 2013.

VEGO, Marko. Naselja bosanske srednjevjekovne države. izd. Sarajevo: Svjetlost, 1957. VELJKOVIĆ, Žarko. „Još jednom o natpisu popa Tøhodraga iz Lištanâ kod Livna. [Osvrt na članak Marić i dr., 'Pop Tjehodrag i njegov natpis', Povijesni prilozi 33, 2007, 9-32]”. Teološki pogledi, knj. LI, sv. 2 (2018): str. 275-317. [orig.] ВЕЉКОВИЋ, Жарко. „Још једном о натпису попа Тъходрага из Лиштана̂ код Ливна. [Осврт на чланак Marić i dr., 'Pop Tjehodrag i nje- 
gov natpis', Povijesni prilozi 33, 2007, 9-32]”. Теолошки погледи, књ. LI, св. 2 (2018): стр. 275-317. УДК: 930.2:003.349.071(497.6)"13”

Žarko B. Veljković

Milan Ž. Vojnović

\section{NUDMIR AND LUDMER: ONCE MORE ON THE SUBJECT OF THE TOPONYM}

The article proceeds from the clarifying and comprehensive article on etymology of the toponym/horonym in Eastern Bosnia Лÿдмер and Лудмѐрија written by Aleksandar Loma, where its author cautiously gave the 'hypothetical reconstruction' as conclusion not being able to find the reliable historical acknowledgments of the name before the year 1900. By further investigation, additional historical acknowledgments of the name has been found, or the new readings of the old ones, during the period years 1530-1712/13, as well as the first reliable historical acknowledgment of the name in the year 1363 in the forms ${ }^{\star} H \ddot{y} \partial м \bar{u} p$ and Hyдмйрuja, in Latin Nudmiria. Loma's etymology has been corrected as the toponym/horonym mentioned originate

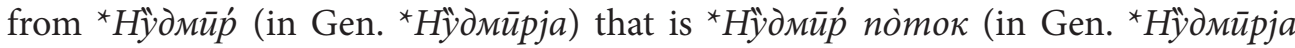
поттока) „Nudmir's brook”, having been derived from the personal name Hÿдмūp, in the older, non-syncopated form, ${ }^{\star} H \ddot{y} \partial u м \bar{u} p$. This antique Serbian personal name Ноүдьмнрь had been recorded in Contributors' names book from Kruševo (Крушевски поменик) from the times before the end of the $15^{\text {th }} \mathrm{c}$., its meaning being "one who (forcibly) compel, coerce into (peace) agreement, peace”, and itself falling to the type of the names in $-\mathcal{M} \bar{u} p$ with negative semantics.

Key words: Лудмер, Лудмерија, Нудмир, Нудмирија, Nudmiria, ${ }^{\star}$ Нудимир, toponym, etymology 